\author{
Sara Snoder \\ Stockholms universitet \\ Christina Hedman \\ Stockholms universitet \\ Joke Dewilde \\ Universitetet i Oslo
}

DOI: http://dx.doi.org/10.5617/adno.8477

\title{
Legitimerad flerspråkighet i utspädd dos - flerspråkiga grundskollärares perspektiv
}

\begin{abstract}
Sammanfattning
Utifrån en kritisk diskursanalytisk lins undersöker föreliggande studie hur fem flerspråkiga lärare i grundskolans tidiga år diskursivt positionerar sin egen flerspråkighet och i förhållande till undervisning, elever, kollegor och vårdnadshavare. Syftet är att bidra med ny kunskap om vilken betydelse lärares flerspråkighet kan ha i undervisningssammanhang i skolans tidiga år. Med en etnografisk ansats genomfördes deltagande observationer i två grundskolor med hög andel flerspråkiga elever (ålder 7-12 år) och lärare. Data består av transkriberade intervjusamtal med de fem flerspråkiga lärarna och fältanteckningar från deras undervisning. Resultaten visar hur lärarnas diskursiva positionering av sin flerspråkighet och av flerspråkig användning tog sig olika uttryck, som rättighet och resurs såväl som problem (Ruíz, 1984). Lärarnas flerspråkiga policy uppfattades ha särskilt stor betydelse i förhållande till vårdnadshavare även om det också fanns uttryck för ambivalens, t.ex. i positionering av språklig behärskning av svenska och andra språk. Negativa upplevelser fanns av att bli positionerad som icke-legitim talare av svenska, jämte uttryck för en mer dynamisk syn på språk och identitet hos några av lärarna. Trots lärarnas legitimering (Van Leeuwen, 2007) av en flerspråkighetspolicy lokalt (Bonacina-Pugh, 2020) utmanades inte svenska som undervisningsspråk i stort, vilket t.ex. var märkbart i uttryckta gränser för användning av andra språk än svenska. Fler liknande fallstudier i ordinarie undervisning i skolans tidiga år behövs, då elever socialiseras in i skolans språkliga register, för ytterligare kunskap om hur flerspråkiga praktiker kan ta sig uttryck, var gränserna går och deras betydelse i dagens heterogena klassrum.
\end{abstract}

Nyckelord: diskursiv positionering, flerspråkighet, flerspråkiga lärare, diskursanalys, språkpolicy 


\title{
Legitimized multilingualism in diluted doses - the perspective of multilingual primary school teachers
}

\begin{abstract}
Through an analytic lens of critical discourse, this study investigates how five multilingual primary school teachers discursively position their own multilingualism in relation to their instruction, pupils, colleagues and caregivers. The aim is to contribute new knowledge on the possible significance of teachers' multilingualism in the early school years. Through an ethnographic approach, participant observations were carried out in two schools with a large proportion of multilingual pupils (ages 7-12 years) and teachers. Data comprise transcriptions from interviews with the teachers and field notes from their instruction. The teachers discursively positioned their multilingualism and multilingual practices as a right, a resource, and a problem (Ruíz, 1984). Teachers perceived the multilingual policy to be particularly important in contact with caregivers, although there were also expressions of ambivalence regarding matters such as the positioning of language proficiency levels of Swedish and other languages. The result included some negative experiences of being positioned by others as non-legitimate speakers of Swedish alongside expressions of a more dynamic view on language and identity among some teachers. Despite expressions of a legitimized (Van Leeuwen, 2007) multilingual policy locally (Bonacina-Pugh, 2020), Swedish as the medium of instruction remained unchallenged, as notable in expressed boundaries regarding the use of languages other than Swedish. Similar studies are needed within mainstream classes in the early school years, where pupils are socialized into the school's language registers, to gain more knowledge on how multilingual practices are expressed, where the boundaries are and their significance in contemporary diverse classrooms.
\end{abstract}

Keywords: discursive positioning, multilingualism, multilingual teachers, discourse analysis, language policy

\section{Introduktion}

Den här studien handlar om flerspråkiga lärare i grundskolans tidiga år i Sverige som arbetar i skolor med hög andel flerspråkiga elever (7-12 år). Andelen grundskollärare i Sverige med utländsk bakgrund utgör nära 20 procent av det totala antalet lärare (Skolverket, 2019b). I tidigare svenska studier har den gruppen av lärare gett uttryck för en komplexitet vad gäller användandet av andra språk än svenska i undervisningen och i kontakt med vårdnadshavare (Bigestans, 2015; Bredänge, 2003; Sandlund, 2010). Positiva erfarenheter visar till exempel att andra språkkunskaper än svenska, som läraren delar med elever och vårdnadshavare, kan uppfattas som trygghetsskapande. Men studier har också visat utmaningar hos utlandsfödda lärare vid användning av svenska inom skolans ram (Bigestans, 2015; Sandlund, 2010).

I den svenska språklagen (SFS 2009:600) framhålls det svenska språket som "huvudspråket", "det allmännas språk” och "det samhällsbärande språket". Språklagen anger även att möjligheten ska ges för den enskilde individen att lära sig, 
utveckla och använda svenska samt beredas möjlighet att utveckla och använda sitt modersmål. I läroplanen för grundskolan framkommer att undervisningen ska främja elevernas fortsatta lärande och kunskapsutveckling utifrån "elevernas bakgrund, tidigare erfarenheter, språk och kunskaper" (Skolverket, 2019a, s. 8, vår kursivering). Här kan språk tolkas som andra språk än svenska. Det är således inte helt tydligt i styrdokumenten vilken roll svenskan har i förhållande till andra språk.

Vidare anger styrdokumenten undervisningens innehåll men inte på vilket sätt undervisningen ska bedrivas. Lärare ges därmed stor frihet att utforma sin undervisning, men ställs samtidigt inför krav som kan uppfattas som utmanande att förena, t.ex. avseende hur elevers och lärares språkliga repertoarer kan komma till uttryck i undervisningen. Föreliggande artikel fokuserar den här otydligheten, eller möjliga ambivalensen, genom att undersöka hur och vad flerspråkiga lärare uttrycker kring flerspråkig användning. Det görs också mot bakgrund av att forskning om flerspråkighet och undervisning ger vid handen att det ofta råder en enspråkighetsnorm i klassrummet, ett monolingual habitus (Gogolin, 2002; se även Lindberg, 2009), trots den språkliga och kulturella mångfald som många klassrum idag uppvisar (Bailey \& Marsden, 2017; Cummins, 2014; Dewilde, 2013; Duek, 2017; Hedman \& Magnusson, 2019; Safford \& Kelly, 2010).

Ett viktigt bidrag är studiens fokus dels på lärare med flerspråkig bakgrund, dels på deras roll som "generalister” i den svenska grundskolans tidiga år, vilket innebär att de undervisar i de flesta ämnen. Denna lärargrupp har inte tidigare specifikt undersökts i förhållande till flerspråkiga undervisningspraktiker.

I föreliggande artikel riktas ljuset specifikt mot fem flerspråkiga lärares syn på sin egen flerspråkighet i undervisning av låg- och mellanstadieelever (7-12 år) för att visa den potential och möjliga friktion som kan göra sig gällande i flerspråkiga undervisningspraktiker. Det övergripande syftet är att bidra med ny kunskap om vilken betydelse lärares egen flerspråkighet kan ha i undervisningssammanhang. Därmed avser studien även belysa möjligheterna för en utökad inkludering av lärares och elevers flerspråkiga repertoarer. Utifrån en etnografisk ansats söks svar på följande frågeställningar: Hur positionerar lärarna diskursivt (i) sin egen flerspråkighet, (ii) sin flerspråkighet i förhållande till undervisning, och (iii) sin flerspråkighet i förhållande till aktörer i skolan (elever och kollegor) och utanför skolan (vårdnadshavare)?

\section{Tidigare forskning om flerspråkiga lärare}

Vi använder begreppet flerspråkiga lärare som en beteckning för lärare som använder flera språk i sin vardag (Li Wei, 2018; Svensson et al., 2018). I forskningen avser flerspråkiga lärare olika typer av lärare, med olika arbetsuppgifter och skilda undervisningskontexter (Conteh, 2018; Conteh et al., 2014). Tidigare forskning har t.ex. belyst flerspråkiga lärare i rollen som såväl modersmålslärare i den ordinarie skolan (Daugaard, 2015; Ganuza \& Hedman, 2015; Reath Warren, 2017) och i undervisning av hemspråk bortom skolans regi (se Creese \& 
Blackledge, 2010, complementary schools; Hall et al., 2002), som studiehandledare (Daugaard \& Dewilde, 2017; Reath Warren, 2017; Rosén et al., 2019), som grund- och gymnasielärare (Bigestans, 2015; Bredänge, 2003; Sandlund, 2010) och som assistenter till lärare som undervisar majoritetsspråket (Creese, 2005; Dávila \& Bunar, 2020; Martin-Jones \& Saxena, 2003).

Till skillnad från tidigare studier fokuserar föreliggande studie specifikt betydelsen av flerspråkigheten hos flerspråkiga generalistlärare som verkar i skolans tidiga år (och ur ett emiskt perspektiv, dvs. den kulturella verkligheten som den erfars och beskrivs av lärarna själva). Som framgår av ovan tematiserar forskningslitteraturen främst flerspråkiga lärares upplevelser av att arbeta som lärare i en ny nationell skolkontext, samt möjligheter och hinder i det arbetet, i synnerhet gällande språkliga aspekter. Endast till viss grad adresseras lärarnas användning av elevernas modersmål och/eller flerspråkighet mer generellt.

I Sandlunds (2010) intervjustudie ger sju utlandsfödda lärare sitt perspektiv på hur det kan vara att byta land men verka i samma profession. Utifrån lärarnas jämförelser av skolkulturer i ursprungslandet med svensk grund- och gymnasieskola framkommer varierade upplevelser, alltifrån liten upplevd skillnad avseende arbetsuppgifter till uttryck för ett hindrat tillträde till lärargärningen på grund av deras brytning på svenska. Lärarna betonade att varje utbildningssystem och skolkultur präglas av både positiva och mindre positiva aspekter av undervisning och lärarstatus (Sandlund, 2010). Liknande resultat finns i studier av flerspråkiga lärares syn på yrket i ursprungslandet jämfört med svensk skola, samt av hur utbildningssatsningar för lärare med examen från annat land fungerat (Jönsson \& Rubinstein Reich, 2006) och av vad som värderas vid anställning av flerspråkiga lärare, skolledar- och lärarutbildarperspektiv (Bredänge, 2003).

I en intervjustudie med 21 utländska lärare i svensk skolkontext fann Bigestans (2015) att flera utländska lärare upplevde språkhinder när det gällde svenska, vilket kom till uttryck genom att lärarna inte ville eller vågade undervisa i den åldersgrupp som de var behöriga att undervisa. Istället undervisade lärarna yngre elever. Flera studier rapporterar också om utländska lärares upplevda utmaningar i interaktion med elever. Förutom att eleverna uppfattades ha större frihet än vad lärarna var vana vid, kunde lärarna också uppleva en språklig osäkerhet, i synnerhet i dialog med kollegor (Bredänge, 2003; Jönsson \& Rubinstein Reich, 2004). Några av lärarna i Bigestans (2015) studie hade utvecklat strategier för att överbrygga språkliga barriärer, t.ex. genom att göra föräldrar uppmärksamma på att de inte hade svenska som förstaspråk eller att uteslutande arbeta som modersmålslärare eller förskollärare.

Ett fåtal studier har belyst på vilket sätt flerspråkiga lärares språkkunskaper och tidigare erfarenheter har utgjort en resurs i ordinarie undervisning (Bigestans, 2015; för en översikt se Svensson et al., 2018). I Sandlunds (2010) studie uppmärksammade t.ex. flerspråkiga lärare olika perspektiv på ett visst tema genom att dra paralleller mellan Sverige och sina respektive hemländer i samtal med elever. Andra uttryckte en önskan om att undervisa matematik på två språk i de 
fall ett större antal elever delade samma språk som läraren, förutom svenska. Lärarna underströk samtidigt att undervisningen i regel inte organiserades på ett sätt som underlättade sådan tvåspråkig undervisning (Sandlund, 2010). Flerspråkiga lärare kunde också använda sina egna erfarenheter av språkinlärning som en resurs i undervisningen eller som modell för andra inlärare. I en tysk studie i skolans tidiga år var de flerspråkiga lärarna mycket motiverade att medvetandegöra elevernas språk i undervisningen. Denna känslomässiga aspekt baserades på lärarnas egna erfarenheter av att ha vuxit upp i en flerspråkig miljö och använda en flerspråkig repertoar (Gilham \& Fürstenau, 2020).

Lärares flerspråkighet i samarbete mellan hem och skola/förskola är ett annat tema i forskningslitteraturen. Bigestans (2015) beskriver hur det gemensamma språket, förutom svenska, mellan förskolan och hemmet ofta utgjorde en kontinuitet för barnet vid lämning/hämtning och hur flerspråkiga lärare lättare kunde förstå vilka formuleringar som kunde vara språkligt och/eller begreppsligt svårtydda i informationsbrev till vårdnadshavare. Även om lärare som har ett gemensamt språk med vårdnadshavare ofta lyfts som en resurs, visar Bigestans (2015) studie att flerspråkiga lärare ändå valde att inte använda andra språk än svenska, trots att möjligheten fanns, såsom i utvecklingssamtal och i samarbete mellan skola och hem. Att användningen av ett gemensamt språk med vårdnadshavare inte nödvändigtvis är okomplicerad, visar även Dewildes (2013) studie. Studien beskriver t.ex. hur en norsk-somalisktalande lärare fick agera tolk vid ett föräldramöte med somalisktalande föräldrar, då läraren kom i lojalitetskonflikt och valde att inte översätta delar av föräldrarnas missnöje med skolan.

\section{Teoretiska utgångspunkter}

Utifrån studiet av diskursiv positionering går det att förklara och förstå individers egen syn på flerspråkighet och hur den kan komma till användning i en undervisningskontext. För en sådan förståelse är Ruíz' (1984) sociolingvistiska begrepp om språk som problem, rättighet och resurs användbara. Nedan redogörs närmare för dessa tre perspektiv på flerspråkighet, samt artikelns tillämpning av begreppen diskurs, diskursordning och positionering. Avslutningsvis diskuteras språklig legitimering i förhållande till språkpolicy i de aktuella skolkontexterna (Bonacina-Pugh, 2020).

\section{Tre perspektiv på flerspråkighet}

Ruíz (1984) framhåller tre förhållningssätt gentemot språk i ett samhälle: språk som problem, språk som rättighet och språk som resurs. Ursprungligen avsåg dessa perspektiv således de värden som underbygger en språkpolicy i ett vidare samhällsperspektiv. De tre perspektiven har dock senare använts mer specifikt i utbildningssammanhang (Hult \& Hornberger, 2016; Ruíz, 2010), där språk som problem innebär ett bristperspektiv på språkanvändaren, medan språk som 
rättighet riktar in sig på de formella rättigheter som en flerspråkig individ har. Det tredje perspektivet, språk som resurs, innebär att individens språkliga repertoar betraktas som något att bevara, utveckla och använda. I forskning om språkpolicy i utbildningssammanhang framhålls dock att perspektiven förutsätter varandra, dvs. att ett språk-som-rättighetsperspektiv, förutsätter en syn på språk-som-resurs (Ruíz, 2010). Utan en sådan helhetssyn riskerar dess delar, som perspektivet språk som resurs, att tolkas i rent instrumentella och ekonomiska termer, vilket kan underminera verkan i en språkpolicy (Hornberger, 2006; Ricento, 2006). Ett helhetsperspektiv innebär även att beakta den växelverkan som finns mellan språkpolicy på ett övergripande institutionellt plan och den språkpolicy som iscensätts i undervisning, vilken både kan öppna upp och begränsa utrymmen för flerspråkig användning (Canagarajah, 2006; Hornberger \& Johnson, 2007). I föreliggande artikel betraktar vi de tre perspektiven som sammanhängande, dvs. vilka står i samspel med och förutsätter varandra. Genom att belysa hur flerspråkiga lärare uttrycker sin egen flerspråkighet och hur de positionerar sig själva, utifrån elever, kollegor och vårdnadshavare, blir perspektiven användbara i syfte att synliggöra hur språk och språkanvändning värderas (Ruíz, 1984).

\section{Diskurs och positionering i ett poststrukturellt perspektiv}

Enligt Foucault (1993) och Foucault et al. (2000) beskrivs diskurs som en specifik praktik som producerar vissa typer av uttalanden. Genom interaktion förhandlar och (om)skapar människor diskurser. En diskurs kan förstås som ett bestämt sätt att tala om och förstå världen. Genom att språkligt i tal och skrift avgränsa världen vi lever i, skapar, omskapar eller bestrider vi diskurser. I diskursbegreppet ingår således också maktperspektivet (Fairclough, 2014), vilket bl.a. innebär individens möjlighet att utmana diskurser och därmed maktpositioner. Den kritiska diskursanalysen avser att undersöka och analysera befintliga maktstrukturer i relation till diskurs(-er), vilket i föreliggande studie innebär analys av diskursiv positionering av flerspråkighet i skolkontext. Synen på språk ur ett poststrukturellt perspektiv innebär att språk ses som ett medel för att förstå och beskriva världen med betydelse för vårt identitetsskapande. Språket både reflekterar och formar världen och individer kan med språk påverka sin omgivning samt sin (makt)position. Det är således dynamiska diskurser som skapar oss som subjekt (Foucault, 1993).

$\mathrm{Vi}$ ansluter oss till Foucaults diskursbeskrivning som en övergripande ram. I detta sammanhang utgör (talet om) flerspråkighet den diskurs som vi fokuserar och utifrån vilken deltagarna positionerar sig. Diskursen flerspråkighet uppstår genom handlingar och den skapar ramar för identitetskonstruktion. Flera diskurser i konkurrens formar en diskursordning (Fairclough, 2014; Foucault, 1993), som kan undersökas avseende vari konkurrensen mellan de olika diskurserna består men också var likheterna återfinns. Det kan således finnas flera diskurser om flerspråkighet samtidigt.

Positionering handlar både om att positionera sig själv och att bli positionerad av andra. Davies och Harré (1990) definierar position som "what is created in and 
through talk as the speakers and hearers take themselves up as persons” (s. 62). I interaktion förhandlar och transformerar individer identiteter genom att positionera sig i relation till andra. Det är genom att agera utifrån de ramar som diskursen sätter upp, som positionen (åter)skapas. Begreppet positionering används i den här studien för att belysa hur diskurser om flerspråkighet konstruerar ramar inom vilka olika former av positionering möjliggörs, eller inte.

\section{Legitimering och språkpolicy}

Ett språks legitimering beror ofta på faktorer som politik, ideologi och ekonomi (Bonacina-Pugh, 2020), varför val av språk i en viss situation beror på kringgärdande maktstrukturer (Heller, 1996). Med de övergripande frågorna för legitimeringshandlingar 'Varför ska vi göra det här?' och 'Varför ska vi göra det på det här sättet?' sätter Van Leeuwen (2007) in begreppet legitimering i ett analytiskt ramverk, och för den här studien blir delar av det ramverket relevant. Authorization ("auktorisation”, vår översättning) åsyftar legitimering via t.ex. lagstiftning, policy eller en viss institution, men kan också innebära personlig eller professionell/expertbaserad auktoritet. En annan form av legitimering är enligt Van Leeuwen (2007) rationalization ("rationalisering", vår översättning), som åsyftar legitimering via institutionaliserat socialt agerande. Här återfinns den teoretiska rationaliseringen, vilken hänvisar till "så som det är" (Van Leeuwen, 2007, s. 103, vår översättning). I en skolkontext kan svaret på varför-frågan vara att något görs för att det är vad som anses mest lämpligt och naturligt av de aktuella aktörerna i skolan (Hedman \& Magnusson, 2020).

Språkpolicy kan komma till uttryck både på makronivå i form av nationella styrdokument, och på mikronivå t.ex. lokalt i ett flerspråkigt klassrum. Ett språks legitimering konstrueras av deltagarna $\mathrm{i}$ en given situation och ett givet sammanhang (Van Leeuwen, 2007). Aktörers kännedom om vilka språk som är legitima att använda i en klassrumskontext och när detta är lämpligt är exempel på ett praktiskt lokalt perspektiv (Bonacina-Pugh, 2020). Det praktiska perspektivet blir i föreliggande studie relevant för att belysa de flerspråkiga lärarnas uttryckta upplevelser av vilket eller vilka språk som av andra eller av deltagarna själva anses vara legitima att bruka.

Trots att det på en utbildningspolitisk (makro)nivå råder en viss språkpolicy, såsom ett legitimerat undervisningsspråk, kan alltså en klassrumspraktiks språkpolicy på (mikro)nivå utgöra en annan än makronivåns i och med aktörernas språkanvändning. Det blir en lokal legitimering utifrån de normer och värden som givits just de språken lokalt i ett klassrum av läraren och/eller eleverna (jfr Bonacina-Pugh, 2020). 


\section{Metod och analys}

En lingvistisk etnografisk utgångspunkt (se t.ex. Agar, 2006; Blommaert \& Jie, 2010) ligger till grund för studien, där fem flerspråkiga lärare på två grundskolor följdes i sin undervisning och intervjuades. Försteförfattaren genomförde sex månaders fältarbete i årskurs 1 (elevålder 7 år), årskurs 2 (elevålder 8 år), årskurs 3 (elevålder 9 år) och årskurs 6 (elevålder 12 år), då fältanteckningar togs, kombinerat med semistrukturerade intervjuer med lärarna. Det är främst de semistrukturerade intervjuerna som utgör empirin för denna artikel. Fältanteckningarna bidrog till intervjuunderlaget i och med att vissa frågor som diskuterades under intervjuerna belyste den observerade undervisningen. Fältanteckningarna bidrog således till möjligheten att i intervjusamtalen lyfta aspekter av lärarnas diskursiva positionering av sin egen flerspråkighet både i förhållande till den egna undervisningen, och i förhållande till eleverna.

Studien följer Vetenskapsrådets forskningssed (Vetenskapsrådet, 2017) och de etiska principer som råder för forskning avseende informationskrav, samtyckeskrav, konfidentialitetskrav samt nyttjandekrav. Etikprövningsmyndigheten har godkänt den forskning som angavs i ansökan. Samtliga deltagare och skolor har givits pseudonym.

\section{Urval}

I studien ingår två kommunala grundskolor belägna i ett svenskt, språkligt heterogent storstadsområde: Guldskolan, en förskoleklass till årskurs 9-skola, och Tennskolan, en förskoleklass till årskurs 6-skola. Vi ville att de skolor som ingick i studien skulle ha en hög andel flerspråkiga elever, dvs. elever som talar fler språk än svenska på en vardaglig basis i hemmet. I praktiken innebar det att skolor valdes där ungefär hälften av eleverna (eller fler) hade "utländsk bakgrund”. Med "utländsk bakgrund" avses utlandsfödda elever eller elever med minst en utlandsfödd vårdnadshavare (Skolverket, 2019b). Kriteriet för deltagande lärare var att de själva uppfattade sig som flerspråkiga i termer av att ha växt upp med andra talade språk än svenska i hemmet. De båda skolornas rektorer och de fem deltagande flerspråkiga lärarna tillfrågades initialt via e-post om deltagande i studien och samtliga gav sitt informerade samtycke till medverkan. Lärarna arbetade under den aktuella perioden i årskurserna, 1, 2, 3 och 6. Tabell 1 ger en översikt av deltagarnas pseudonymer, aktuell skola, deltagarnas språk (i bokstavsordning), antal år i Sverige, utbildning/examen, antal år i yrket och i vilka årskurser de undervisade. 
Tabell 1. Översikt över de intervjuade lärarna

\begin{tabular}{|l|l|l|l|l|l|l|}
\hline Namn & Skola & Språk & År i Sverige & Examen & År i yrket & Årskurs \\
\hline Gloria & Guldskolan & $\begin{array}{l}\text { bulgariska, } \\
\text { engelska, } \\
\text { svenska }\end{array}$ & $\begin{array}{l}\text { Förskollärare, } \\
\text { Grundskollärare 1-71 }\end{array}$ & 12 & 2,6 \\
\hline Gabriel & Guldskolan & $\begin{array}{l}\text { engelska, } \\
\text { svenska, } \\
\text { turkiska }\end{array}$ & $\begin{array}{l}\text { Född i } \\
\text { Sverige }\end{array}$ & Grundskollärare F-32 & 1,5 & 3 \\
\hline Therese & Tennskolan & $\begin{array}{l}\text { engelska, } \\
\text { grekiska, } \\
\text { svenska }\end{array}$ & 5 & Grundskollärare F-3 & 0,5 & 3 \\
\hline Tina & Tennskolan & $\begin{array}{l}\text { engelska, } \\
\text { svenska, } \\
\text { turkiska }\end{array}$ & $\begin{array}{l}\text { Född i } \\
\text { Sverige }\end{array}$ & Grundskollärare F-3 & 6 & 1 \\
\hline Tea & Tennskolan & $\begin{array}{l}\text { arabiska, } \\
\text { engelska, } \\
\text { svenska }\end{array}$ & $\begin{array}{l}\text { Född i } \\
\text { Sverige }\end{array}$ & Grundskollärare F-3 & 1 & 3 \\
\hline
\end{tabular}

11-7 står för grundskolans årskurs 1 till 7. ${ }^{2}$ F-3 står för förskoleklass till årskurs 3.

\section{Intervjuer: insamling}

De ljudinspelade semistrukturerade intervjuerna med lärarna genomfördes av försteförfattaren på respektive skola i ett ostört rum och varade 40-75 minuter. Intervjuerna genomfördes i slutet av fältarbetet på respektive skola, då intervjufrågorna kunde adressera den undervisning som hade observerats. Syftet med intervjuerna var att erhålla ett emiskt perspektiv, dvs. en förståelse av det studerade fenomenet utifrån deltagarna (Copland \& Creese, 2015). Intervjuerna behandlade bl.a. frågeställningar kring deltagarnas språkbakgrund, deras syn på språkanvändning i undervisningen och deras upplevda legitimitet som svensktalande. Exempel på temafrågor var: Hur har du upplevt din språkliga identitet? Har du funderat på din flerspråkighet? Har du haft användning av din flerspråkighet? Hur?

Studiens fokus på språklig interaktion baserades i ett synsätt ad modum lingvistisk etnografi där ett fokus på hur språk används relateras till vad det kan säga om en större social kontext eller social struktur och dessas underliggande ideologier (Copland \& Creese, 2015). Intervjusamtalen utgick från synen på intervjuer som en social praktik (Talmy, 2011), vilket innebär att samtalet tolkas utifrån både vad som sägs och hur det sägs, samt själva samtalskontexten. Utgångspunkten är således att intervjuerna tillsammans med deltagarna skapar en interaktionell praktik (De Fina, 2019) i vilket samtalet kan röra sig åt olika håll, där ämnen fördjupas eller berörs mer översiktligt beroende på deltagarens respons.

Även transkriberingsarbetet betraktas som en praktik som utgår ifrån metodologiska, ideologiska och teoretiska val (Ochs, 1979). Såväl urval som representation av tal avser att vara rättvisande för både vad som sades och hur det sades (Bucholtz, 2000). Således var ett viktigt val utifrån studiens syfte och teoretiska ramverk - inklusive en reflexiv hållning hos författarna - att efter genomlyssningar av intervjuerna, transkribera aktuella delar ortografiskt (Ochs, 
1979). Intervjuerna transkriberades således med detaljer såsom pauser, emfas och inandningar för att i analysarbetet tolka både innehåll och hur innehållet framställdes (se Transkriptionsnyckel).

\section{Intervjuer: analys}

Den initiala analysen av de transkriberade intervjuerna var huvudsakligen datadriven (Bryman, 2018). Intervjuerna lästes först igenom var för sig ett flertal gånger i syfte att få god kännedom om varje enskild intervju och sedan av samtliga intervjutranskriptioner efter varandra, för att få ett helhetsperspektiv. Vid uppföljande genomläsningar användes färgkodning av meningsenheter och teman (Ryan \& Bernard, 2003) med forskningsfrågorna som utgångspunkt. De fyra temana som arbetades fram var relationen till och synen på sin egen flerspråkighet, ambivalent flerspråkig användning, legitimitet som svensktalande och samarbete hem-skola. Dessa teman framträdde även på basis av försteförfattarens temafrågor som fanns inbäddade i intervjun (se ovan), liksom att intervjuaren är modersmålstalare av svenska med god kännedom om såväl skolkontext som läraryrket (jfr Rampton et al., 2015; Salö, 2018). Den induktiva analysen övergick därefter i en mer abduktiv process i vilken data och teori växelverkade (Kvale \& Brinkmann, 2014).

\section{Resultat}

Presentation och diskussion av resultaten är baserad i ovan beskrivna teman. Avslutningsvis förs en sammanfattande diskussion utifrån resultaten.

\section{Relationen till och synen på sin egen flerspråkighet}

De fem flerspråkiga lärarna gav olika uttryck för den egna flerspråkigheten. Två av dem sade sig inte ha funderat nämnvärt på sin flerspråkighet (Tina och Gabriel, båda födda i Sverige), vilket Exempel 1 och 2 visar, när intervjuaren frågade om de hade funderat på sin flerspråkighet och språkidentitet. Tina ger uttryck för sin flerspråkighet som icke utstående, vilket framgår av Exempel 1.

Exempel 1

01 Intervjuare:

02 Tina:

03

04 Intervjuare:

05 Tina:

06 Intervjuare:

07 Tina:

08

09

10 Intervjuare: din språkidentitet hur har du upplevt den?

jamen jag har alltid nä men asså

jag har alltid sett det som en styrka hos mig

$\mathrm{mm}$

eh:hh (.hhh) faktiskt (1.0) att kunna ett annat språk

$\mathrm{mm}$

men nä::ä jag vet inte jag har nog inte lagt så

mycket eh::hh tid på att tänka det har varit så naturligt för

mig

$\mathrm{mm}$ 
11 Tina:

12 Intervjuare:

13

14 Tina: (.hhh) har det

du har aldrig känt dig (.hhh) nu lägger jag orden i din mun men såhär splittrad eller?

nä nä::ä

Tinas betoning av sin flerspråkighet som något "naturligt” indikerar en positionering av den egna flerspråkigheten som förgivettagen och naturaliserad (jfr den teoretiska rationaliseringen, Van Leeuwen, 2007). I Exempel 1 tolkar intervjuaren Tinas svar och söker få sin tolkning bekräftad genom frågan om Tina känt sig "splittrad" med anledning av sina flera språk. Här introducerar således intervjuaren flerspråkighet som något potentiellt anmärkningsvärt som dessutom kan vara negativt eller splittrande. Tinas svar i form av upprepande "nä" visar att det är något hon bestrider med emfas. En tolkning är att talturerna ger uttryck för kolliderande diskurser, där flerspråkighet som problem ("splittrande") möter Tinas betoning av sin flerspråkighet som självklar och som en "styrka” i linje med Ruíz' (1984) kategorisering av flerspråkighet som resurs och tillgång (Hult \& Hornberger, 2016). Även Gabriels hållning i Exempel 2 - att han inte tror sig ha tänkt särskilt mycket på sin flerspråkighet - ligger i linje med bestridandet av en diskurs där flerspråkighet skulle vara ett avsteg från det normala i skolan. I Exempel 2 har Gabriel tidigare uppgett att han talar två modersmål, svenska och turkiska.

Exempel 2

01 Intervjuare: $\quad$ Har du tänkt på det [din flerspråkighet] själv?

02 Gabriel: $\quad$ (2.0) jag tror faktiskt inte det

03 Intervjuare: nä nä

04 Gabriel: jag tror inte det

Gabriels paus följt av ett upprepat "jag tror inte det” kan ses ligga i linje med Tinas svar på frågan om språkidentitet ("har nog inte lagt så mycket tid att tänka på det”). Hans svar kan tolkas som att han också ser sin flerspråkighet som något förgivettaget som han inte har behövt fundera närmare på (jfr Fairclough, 2014). Senare i intervjun (se Exempel 5) menar dock Gabriel att han har svårt att uttrycka sig på turkiska på ett mer avancerat sätt, vilket han dock inte relaterar till den allmänna frågan om hans flerspråkighet i Exempel 2. Det visar möjligen att flerspråkig identitet för Gabriel inte är starkt kopplad till språkbehärskning på en viss nivå (se nedan om essentialistisk syn på språk och identitet).

I intervjun med Gloria (född i annat land än Sverige) kommer samtalet in på känslan av tillhörighet $\mathrm{i}$ ett nytt land. Utifrån frågan om upplevd nationell tillhörighet, framträder en annan typ av spänning kring positionering.

Exempel 3

01 Intervjuare:

men det kan finnas situationer när du känner

02

å vad är du då då om du inte är svensk, inte

03 bulgar? 
04 Gloria:

05 Intervjuare:

06 Gloria:

07

08 Intervjuare:

09 Gloria:

10 Intervjuare:

11 Gloria:
(2.0) $\mathrm{mm}$ det vet jag inte

nä

i såna situationer så definierar mig svenskar som utlänning

i Bulgarien dom definierar mig som svensk

$\mathrm{mm}$

så::å det man splittras lite däremellan

$\mathrm{mm}$

eh::h (1.0) vilken identitet man har undrar man a::a

Gloria besvarar först frågan om upplevd nationell tillhörighet med (epistemisk) osäkerhet "mm det vet jag inte", ett yttrande som inleds med en lång paus. Det efterföljande svaret reflekterar dock en problematisk positionering av hennes nationella tillhörighet, då hon uttrycker avsaknad av tillhörighet eller "splittring" mellan tillhörigheter i det att andra svenskar inte betraktar henne som svensk i Sverige och i relation till sitt forna hemland positioneras hon som svensk. Gloria uttrycker således, till skillnad från Tina och Gabriel (Exempel 1 och 2), mer av en kamp när det gäller hur andra positionerar hennes "svenskhet”. I Exempel 3 bestrider dock Gloria det intervjufrågan antyder, dvs. att hon själv skulle positionera sig som "icke-svensk". Det är snarare så hon positioneras av andra. Gloria uttrycker dock sin identitet som splittrad med anledning av andras potentiella ifrågasättande av hennes nationella tillhörighet. Gloria kan på så sätt här ses bestrida en essentialistisk syn på nationell tillhörighet i vilken det antas finnas en nära och given koppling mellan språklig kompetens och (nationell) identitet (Ag \& Jørgensen, 2013).

I samtal med läraren Tea, som är född i Sverige, framkommer att hon upplever sig ha rötter i tre nationella kontexter, både i Sverige och i sina föräldrars olika ursprungsländer (Exempel 4).

\section{Exempel 4}

01 Intervjuare:

02

03

04 Tea:

05 Intervjuare:

06 Tea:

07 Intervjuare:

08 Tea:

09

10 Intervjuare:

11 Tea:

12

13 Intervjuare:

14 Tea:

15 Intervjuare:

16 Tea: eller då (1.0) det här som vi pratar om (2.0) var hör jag hemma? Jag är utlänning där (1.0) eller invandrare här eller va är jag liksom?

asså jag känner lite grann (.) jag har rötter i [land]

$\mathrm{m}: \mathrm{m}$

jag har rötter i [land]

$\mathrm{mm}$

å jag känner mig lite (1.0) att jag har

bildat egna rötter i Sverige också

$\mathrm{mm}$

så jag skulle säga kanske (.) en tredjedel

om man tänker lite sådär

mm. Är det ett problem för dig?

nä:ä

(.hhh) nä

nej (.) det tycker jag inte 
Teas förhållningssätt kring tematiken om nationell identitet skiljer sig från de övrigas genom att hon utifrån intervjufrågan betonar att hon har rötter i såväl sina föräldrars hemländer som i Sverige. Med emfas ("egna”) förstärker hon att hon i Sverige funnit sina egna rötter och bekräftar att detta inte är ett problem. Med denna emfas kan även Tea antas fjärma sig från en essentialistisk diskurs om ursprung/nation och identitet till förmån för en mer dynamisk syn på (nationell) identitet (jämför Foucaults, 1993, tal om hur dynamiska diskurser formar oss som subjekt).

I främst två av intervjuerna, med Gabriel och Gloria, framkommer att de inte upplever att de behärskar sina andra språk (turkiska respektive bulgariska) på en nivå som de menar sig behöva för att undervisa på dessa språk (Exempel 5 och $6)$.

\section{Exempel 5}

01 Gabriel:

02 Intervjuare:

03 Gabriel:

04

05 Intervjuare:

06 Gabriel:

07 Intervjuare:

08 Gabriel:

09

10

11 Intervjuare:

12 Gabriel:

13

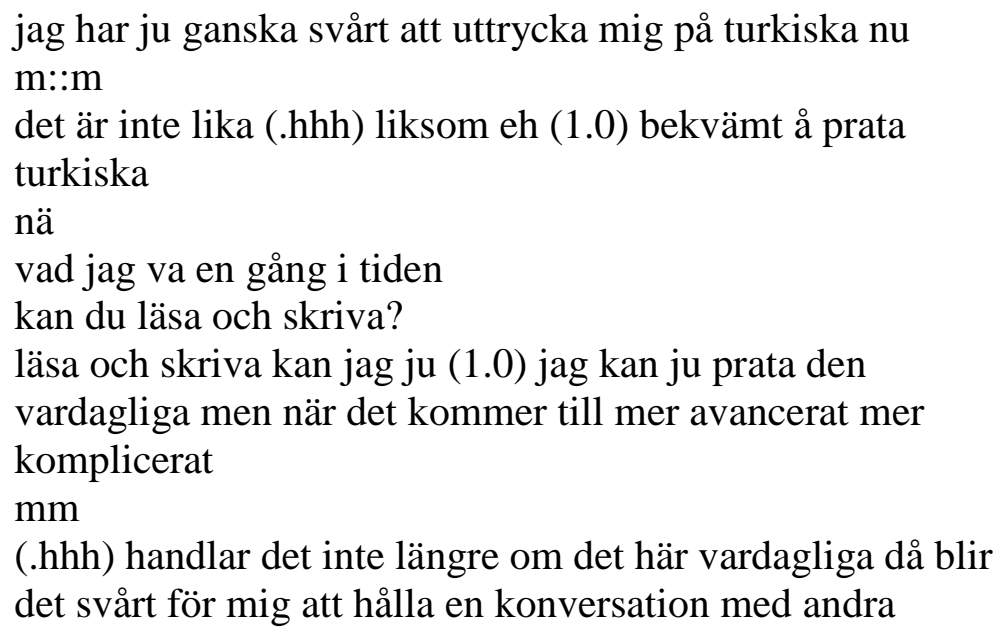

Gabriel uttrycker att hans ordförråd på turkiska är för begränsat för ett "mer avancerat mer komplicerat" språkbruk, bortom konversation om vardagliga ting. Även Gloria, som till skillnad från Gabriel inte är född i Sverige, uttrycker att hennes modersmål blivit "torftigt” i och med flytten till Sverige för 26 år sedan.

Exempel 6

01 Gloria:

02

03 Intervjuare:

Fast i mitt fall kan jag säga jag inhämtar bättre

04 Gloria:

05

information på svenska efter så många år i Sverige

ja jo

eh (1.0) så det blir en vändning (.) efter så många år som

man

06 Intervjuare:

a::a

07 Gloria:

08

bor i ett annat land (1.0) å i mitt yrke så är det svenska i

fokus

09 Intervjuare:

ja

10 Gloria:

11

12 Intervjuare:

eh då blir en vändning att jag inte har utvecklats i

modersmålet

nä

13 Gloria: 
Gloria uttrycker hur hennes yrkesspråk har utvecklats på svenska och antyder också att andra språkliga domäner inte kunnat utvecklas på "modersmålet”. Ett tydligt bristperspektiv framträder i Glorias framställning av sitt "torftiga" modersmål och i Gabriels fall inte som en tillräcklig resurs avseende undervisning. Exempel 5 och 6 visar de avsevärda svårigheter som kan finnas med att utveckla ett minoritetsspråk i en majoritetsspråkskontext, oavsett om man utvecklat minoritetsspråket i en majoritetsspråkskontext från början eller inte.

\section{Ambivalent flerspråkig användning}

Framför allt gav tre av de fem flerspråkiga lärarna, Tina, Tea och Gabriel, explicit uttryck för att ha användning av andra språk än svenska i sin lärarprofession. Det uteslöt dock inte att en ambivalens gällande användning av andra språk än svenska uttrycktes under intervjuerna (se Exempel 7 och 8).

Exempel 7

01 Intervjuare:

02

03 Tea:

04 Intervjuare:

05 Tea:

06 Intervjuare:

07 Tea:

08 Intervjuare:

09 Tea:

10 Intervjuare:

11 Tea:

12 Intervjuare:

13 Tea:

14 Intervjuare:

15 Tea:

16

17 Intervjuare:

18 Tea:

19 Intervjuare:

20 Tea:

21 Intervjuare:

22 Tea:

23 men återigen om ehm du har ju nåra kollegor som i::nte kan arabiska

$\mathrm{mm}$

å som har liksom det här är ju en eno::rm fördel

$\mathrm{mm}$

en enorm fö::rdel

första gången jag tog till arabiska på lektionstid

aa

va jag lite osäker

ja

eh (1.0) ska jag ska jag inte

$\mathrm{mm}$

men när jag upptäckte att det verkligen hjälpte

aa

då kände jag att (.hhh) jamen varför ska jag inte använda arabiska

nä

det är ju inte så att jag använder det hela tiden

nä

men vid speciella tillfällen asså tillfällen

$\mathrm{mm}$

då vore det synd att ta den här fördelen från dom här barnen när man ändå ser att dom gör det dom ska

I Exempel 7 går att skönja en ambivalens hos Tea, då hon initialt inte ville använda arabiska, men sedan ändå gjorde det, och då tyckte sig se fördelarna för en del elever. Mot bakgrund av att svenska är det givna undervisningsspråket formas här en lokal interaktiv diskursiv praktik som utmanar en språklig maktordning (Bonacina-Pugh, 2020). Det finns dock i Exempel 7 en explicit gräns för hur stora avsteg från en sådan diskursordning (se Fairclough, 2014) som kan ges uttryck för i det att Tea försäkrar intervjuaren om att "det är ju inte så att jag använder det hela tiden" och "vid speciella tillfällen”. 
Tea uttrycker också en ambivalens gällande användning av arabiska med vårdnadshavare (Exempel 8).

Exempel 8

01 Tea:

02

03

04 Intervjuare:

05 Tea:

06 Intervjuare:

07 Tea:

08

09

10

11

12 Intervjuare:

13 Tea:

14

15

16

17

18 Intervjuare:

19 Tea:

så de första månaderna höll jag mig som att var kommer du ifrån ah men det spelar ingen roll vart jag kommer från vi är i skolan (.) vi ska prata svenska

du sa inte ens att du kunde arabiska?

nej nä men sen kom det fram

$\mathrm{m}: \mathrm{m}$

man kan ju inte hålla sin identitet hemlig eh (2.0) å det

kom fram å då va det likadant (.) vissa föräldrar

försökte

ta för givet eh men jag har hållit mig liksom på avstånd å satt gränser

$\mathrm{mm}$

att eh (1.0) jag är här för era barns skull (.) om min

arabiska gynnar era barn absolut jag tar det som en

fördel

men eh (.) det gynnar inte dom att jag kommer ha mer

extratid med dom bara för det

nä

bara för att vi är från samma land eller att vi pratar samma språk

Exempel 8 visar Teas initiala övertygelse om att endast använda svenska, både i undervisningen och i kontakt med vårdnadshavare, vilket kan tolkas som reproducerande av nämnda diskursordning i skolan i termer av 'det är så vi gör' (Van Leeuwen, 2007). När det senare "kom fram” att Tea även talar arabiska uttryckte hon sin gränsdragning genom uttalandet att inga elever skulle gynnas av det i form av "extratid". Teas hållning ligger i linje med en rationalisering 'så som det är', dvs. en legitimering via institutionaliserat socialt agerande (Van Leeuwen, 2007), i vilken hon visar att andra språk än svenska kan användas men utifrån av henne givna ramar och utifrån en moralisk värdering som rör rättvisa i klassrummet.

Sammantaget visar exemplen 7 och 8 viss ambivalens rörande flerspråkig användning i undervisning och med vårdnadshavare. Till en sådan ambivalens hör även Gabriels och Glorias syn på sin egen bristfälliga modersmålsanvändning (Exempel 5 och 6). Givet gällande diskursordning, med svenska som undervisningsspråk, kan det således ändå skapas diskurser i vilka aktörer (lärare och elever) använder andra språk, dock med uttalade gränser.

\section{Legitimitet som svensktalande}

Av de fem lärarna var det Gloria och Therese som lärt sig svenska i vuxen ålder, medan Tina, Tea och Gabriel var uppvuxna i Sverige med svenska och ytterligare ett talat språk i hemmet. Det var också i samtal med Gloria och Therese som en upplevd osäkerhet gällande deras legitimitet som svensktalande kom fram. Gloria berättade om elever och kollegor som både hade ifrågasatt och negativt påtalat 
hennes legitimitet som svensklärare, samt gett uttryck för brister i hennes svenska. Hon uttryckte även att hon blivit ledsen över dessa kommentarer. Exempel 9 åskådliggör hennes uttryckta upplevelser av osäkerhet i förhållande till sin användning av svenska i skolan, vilken formats av tidigare negativa erfarenheter som hon ger exempel på.

\section{Exempel 9}

01 Intervjuare:

02

03 Gloria:

04

05 Intervjuare:

06 Gloria:

07 Intervjuare:

08 Gloria:

09

10 Intervjuare:

11

12 Gloria:

13

14 Intervjuare:

15 Gloria:

(...)

16 Gloria:

17

18

19

20

21 Intervjuare:

22 Gloria:

23 Intervjuare:

24 Gloria:

25

26

27 Intervjuare:

28 Gloria:

29

30

31

32

33

34 men du bär alltså fortfarande (.) på känslan av osäkerhet kring språket [svenska]?

ja ja::a (.) jag har ju min kollega här (1.0) som fortfarande garvar hm::m men nu har jag blivit mycket säkrare garvar?

om jag säger något fel

a::a (1.0) garvar personen å::åt dig eller me::ed dig?

åt mig (.) åt mitt språk (1.0) eller hur jag uttalar det

a::ah (.hhh) m::m

eh::eh (.) nu lägger jag orden i din mun (1.0) men alltså

en elak kollega?

a::a nej inte elak (1.0) men ironisk kommentar

som gör ont a::a hon lyfter upp det jag har sagt fel

$\mathrm{mm}$

men på ett sätt som sårar

å mitt i nån ingenstans (.) så säger den här eleven att (.)

ja::a lär dig svenska först (1.0) säger han till mig (.hhh)

hm::m nu skra::attar jag (.) men det va inte kul jag visste

inte

vad jag skulle svara tillbaka

jag blir också helt må::ållös

ehe::e

vad sa dom andra eleverna?

a::a nåra sa (.) a::a sluta å andra skrattade hm så det

va lite blandade eh så (1.0) fast att jag va väldigt sårad

och fast att jag mådde inte alls bra då (.)

$\mathrm{mm}$

eh så hämtade jag lite kraft (.hhh) å så svarade jag tillbaka såhär (.hhh) att ve::et du vad (1.0) om du har åsikt om min svenska å så (.) kan du diskutera det med dina föräldrar så kan ni sen framföra åsikt om saken till ledningen (.) för att det är faktiskt ledningens beslut att anställa mig här och undervisa i svenska så ahm lite såhär (.) diplomatiskt svar

Den första delen av Exempel 9 lyfter fram Glorias motstånd mot en kollegas tidigare positionering av henne som icke-legitim svensktalande (jfr Van Leeuwen, 2007). Gloria uttrycker å ena sidan sin säkerhet som pedagog och å andra sidan en parallellt existerande upplevelse av att inte språkligt ges "rationell” och institutionellt sanktionerad legitimitet (Van Leeuwen, 2007). I Exempel 9 
framkommer även hur en elev uttrycker att Gloria ska "lära sig svenska innan hon undervisar dem”, vilket reflekterar en situation i vilken hennes professionella expertis ifrågasätts (Van Leeuwen, 2007). För att återuppta sin auktoritet, hänvisar hon till skolledningen, en annan auktoritet än henne själv. En upplevd ambivalens gällande denna bristande legitimitet som svensktalande kan tolkas som en positionering av hennes flerspråkighet utifrån perspektivet språk som problem (Ruíz, 1984).

Att ha lärt sig svenska som vuxen innebär för Therese, enligt henne själv, att hon upplever sitt ordförråd rikare avseende yrkesrelaterad och akademisk vokabulär jämfört med sitt mer vardagliga ordförråd (jämför Gloria i Exempel 6) som man tillägnar sig under uppväxten. Det kunde hon ibland märka av i samtal med sina elever. Trots att hon alltid sade sig vara väl förberedd genom att t.ex. ha läst igenom texter som används i klassen, kunde det dyka upp ord som eleverna bad henne förklara och som hon inte alltid kunde (Exempel 10).

Exempel 10

01 Therese:

02 Intervjuare:

03 Therese:

04

05

06: Intervjuare:

(...)

07 Therese:

08 Intervjuare:

09 Therese:

10 Intervjuare:

11 Therese:

12 Intervjuare:

13 Therese:

14 ibland tänker jag på det (1.0) eh::h

när då till exempel?

aa till exempel när jag är jag behöver förklara nånting

för mina elever eh::h å jag fastnar ibland att

hitta lämpliga ord att förklara

$\mathrm{mm}$

man kan höra att jag inte har svenska som modersmål

okej

att jag inte är (1.0) uppvuxen här

hm::m

på att jag inte har den här melodi::n som en svensk har

$\mathrm{mm}$

eh å ibland kan det va svårt (1.0) att eh inte uttala

rätt till exempel när jag pratar snabbt

Therese lyfter i Exempel 10 den osäkerhet hon ibland kan uppleva kring sitt ordförråd på svenska i klassrummet och "att man kan höra att hon inte har svenska som modersmål”.

I motsats till Gloria berättar dock inte Therese om ifrågasättande eller negativa kommentarer gällande sin svenska, varken av kollegor, elever eller vårdnadshavare. Däremot positionerar hon, i likhet med Gloria, sin egen användning av svenska som bristfällig, främst avseende språkmelodi med hänvisning till att hon lärde sig svenska i vuxen ålder (jfr Boyd, 2003). Inget i materialet pekar dock mot att Therese positionerar sina svenskkunskaper som illegitima för det arbete hon ska utföra. I intervjumaterialet hänvisar hon till sitt starkare "akademiska” ordförråd, vilket signalerar eller bekräftar ett möjligt säkerställande av hennes legitima språkkunskaper på svenska för att kunna undervisa. 
Givet att svenska är undervisningsspråket i den undersökta skolkontexten blir det däremot tydligt i Exempel 9 att den svenska som Gloria talar inte ges legitimitet (av en kollega och av en elev). Glorias reflektion kring det kan tolkas som en sanktionering av diskursordningen att en viss svenska förväntas talas i och med hennes hänvisning till annan auktoritet än sig själv. Exempel 9 reflekterar en viss kamp om det diskursiva tolkningsutrymmet och diskursens maktförskjutande potential.

\section{Samarbete hem-skola}

Både Tina och Tea berättade att de genomfört utvecklingssamtal på andra språk än svenska. Exempel 11 tar avstamp i intervjuarens fråga om Tina ibland använder tolk under sina utvecklingssamtal.

\section{Exempel 11}

01 Intervjuare:

02 Tina:

03 Intervjuare:

04 Tina:

05

06 Intervjuare:

07 Tina:

08

09

10 Intervjuare:

11 Tina: har du tolk ibland?

jag hade det när det va serbiska mm (.) men dom andra behövs inte?

jag hade en spansktalande men hennes pappa kan inte svenska han har inte bott här så länge

nä

eh (.) ja nä Tyras mamma kan inte svenska men vi pratar engelska hon å jag

då behövs det ingen tolk

(.hhh) nä

för dom kan det (1.0) nä jag har inte behövt det

I Exempel 11 uttrycker Tina att hon använder tolk endast i de fall det behövs, dvs. när Tina och vårdnadshavare inte talar ett gemensamt språk och vårdnadshavaren inte heller talar svenska i den utsträckningen som situationen kräver. Tina tycks i det här fallet se språkvalet som en naturlig och förgivettagen del av denna situation, som en "personlig legitimering" (Van Leeuwen, 2007), genom att hon med sina språkkunskaper har möjlighet att påverka situationen.

Att intervjuaren ställer frågan om Tina använder tolk och/eller har behov av tolk ibland går även att se som ett antagande om att tolk inte alltid behövs, givet vetskapen att både Tina och en del vårdnadshavare talar samma språk. När Tea får frågan om hur hon ställer sig till att använda andra språk än svenska under utvecklingssamtal, visar svaret att hon finner att användningen av tolk till och med vore "löjligt" i de fall vårdnadshavare och hon talar samma språk förutom svenska.

Exempel 12

01 Intervjuare:

02 Tea:

03 Intervjuare:

04 Tea:

05 utvecklingssamtal (.)

$\mathrm{mm}$

har du haft det på arabiska också?

ja det gör jag bara för å undvika det här med tolken (.)

jag eh (.) det känns löjligt tycker jag 
06 Intervjuare:

07 Tea:

08 Intervjuare:

09 Tea:

10 Intervjuare:

11 Tea:

12 Intervjuare:

13 Tea: $\mathrm{mm}$

å ha tolk tycker jag (.) som ska översätta samma språk

är barnet med då?

ja::a

å då pratar ni arabiska?

$\mathrm{mm}$

alla (.) allihop liksom?

ja::a

Exempel 12 visar Teas inställning till att använda det språk som bäst gynnar vårdnadshavare i syfte att ge dem kännedom om sitt barns utveckling, vilket just kan vara att använda hela sin språkliga repertoar, inte bara det ena eller det andra språket. Exemplet visar även att det gemensamma språket, förutom svenska, används av alla tre parterna under samtalet: lärare, vårdnadshavare och elev. Flerspråkig användning ses således här både som resurs och rättighet (Ruíz, 1984) i samarbetet mellan hem och skola.

\section{Diskussion}

Resultaten visar att deltagarnas diskursiva positionering inte sker på ett entydigt sätt, då flerspråkigheten framträder som rättighet och resurs såväl som problem. Medan egen flerspråkighet och flerspråkig identitet kunde uttryckas som det naturliga och "rationella" (Van Leeuwen, 2007), uttrycktes större ambivalens avseende flerspråkig användning i förhållande till undervisning.

Samtidigt som de flerspråkiga lärarna gav uttryck för en positiv syn på flerspråkig kompetens, och en välvillig inställning till flerspråkig användning i undervisningssammanhang, uttrycktes en ambivalens av olika skäl. Möjligheterna att använda sina flerspråkiga resurser var dels avhängiga hur många elever som delade lärarnas språkliga repertoar, dels av de flerspråkiga lärarnas språkliga behärskningsnivå på sina andra "modersmål” utöver svenska. Som anförts, finns även en otydlighet i styrdokumenten kring hur flerspråkig användning kan iscensättas och vad som faktiskt förväntas. En sådan otydlighet avspeglas sannolikt både i lärarnas ambivalenta positionering av sin egen flerspråkighet och av potentiellt utrymme för flerspråkig användning i undervisningen, givet en antagen växelverkan mellan makrodiskurser (i styrdokument) och lokala diskurser om flerspråkighet (t.ex. Hornberger \& Johnson, 2007).

En ambivalens framkom tydligast hos läraren Tea som initialt tvekade att använda arabiska med elever och vårdnadshavare, men som med tiden fann mest fördelar med att göra det, om än med uttryckta gränser. Flerspråkighet som resurs kan på så sätt villkoras av läraren i den aktuella undervisningsmiljön. Svenska är det givna undervisningsspråket, samtidigt som undervisningen enligt styrdokumenten ska ta fasta på elevernas tidigare erfarenheter och språk. Ett uttryck för den vagheten är, menar vi, lärarnas gränsdragningar av sin flerspråkiga 
användning, även när lärare delade andra språk än svenska med sina elever. Lärarnas flerspråkiga användning visade sig utgöra en särskild betydelsefull resurs för kommunikationen med vårdnadshavare, vilket framkom tydligare här än i t.ex. Bigestans (2015) studie. En sådan fördel i hem-skola samverkan kan även tänkas bidra till de flerspråkiga lärarnas ökade status lokalt. Samtidigt uttryckte lärare en oro för att vårdnadshavare kunde förvänta sig fördelar i och med skapande av en språklig in-grupp (jfr Wodak, 2009). Detta gör sammantaget att en praktisk språkpolicy på lokal nivå baserad i ett resursperspektiv kan konstrueras utan att den språkliga diskursordningen ändras i stort (jfr BonacinaPugh, 2020).

Till det kom att lärarna på olika sätt positionerade sig själva, och positionerades av andra, som legitima språkanvändare av svenska i undervisningen. En lärare, Gloria, uttryckte erfarenheter av att bli positionerad av andra som ickelegitim talare av svenska och att hon fått försvara sin expertauktoritet (Van Leeuwen, 2007) i förhållande till både elever och kollegor. Trots det framkom inte hos någon av deltagarna att de inte vågat eller velat undervisa på det stadium de var utbildade för (jfr Bigestans, 2015). Inte heller förekom, som i Sandlunds (2010) studie, att de flerspråkiga lärarna upplevt hindrat tillträde till lärartjänst på grund av sin brytning på svenska. Våra resultat visar vidare att positionering om flerspråkighet i den här kontexten inte lätt låter sig avskiljas från positionering av nationell tillhörighet eller "svenskhet". I vårt material ser vi ett möjligt bestridande av en alltför essentialistisk syn på språk och identitet och exempel på uttryck för en mer dynamisk språksyn hos de flerspråkiga lärarna.

De flerspråkiga lärarnas positionering i föreliggande studie utgör viktig kunskap för skolan och för ordinarie undervisning i skolans tidiga år. Även om de lokala flerspråkiga policypraktikerna som diskuteras här inte bryter mot en språklig maktordning i stort, är det viktigt, menar vi, att syna hur de flerspråkiga lokala praktiker som finns tar sig uttryck och var gränserna går. Vi menar, att det är särskilt viktigt i de tidiga åren i ordinarie undervisning, då elever socialiseras in i skolans språk och litteracitet.

Flerspråkig användning, där elevers och lärares hela språkliga repertoar tas tillvara, torde i ljuset av den här studien kunna ges större utrymme och möjligen även andra utrymmen i språkligt heterogena klassrum där flerspråkiga lärare finns. Det finns därmed behov av liknande fallstudier med flerspråkiga lärare i de tidiga skolåren för en fördjupad diskussion om flerspråkighetens möjligheter och begränsningar i skolan. Tillvaratagandet av de flerspråkiga lärarnas och elevernas språkliga resurser, utifrån deras perspektiv, skulle behöva diskuteras ur såväl ett demokratiskt värdegrundsperspektiv som ett språkfunktionellt perspektiv med sikte på skolframgång. 


\section{Transkriptionsnyckel}

(.)

$::$

?

(...) paus kortare än en sekund

paus mätt i sekunder

hörbar inandning

förlängning av föregående ljud

fråga

sekvens utelämnad

emfas

\section{Om författarna}

Sara Snoder är doktorand i språkdidaktik vid Stockholms universitet. Hennes avhandlingsprojekt handlar om flerspråkiga grundskollärares perspektiv på sin egen och elevers flerspråkighet samt möjliga utrymmen för flerspråkiga undervisningspraktiker.

Institutionsanknytning: Institutionen för språkdidaktik, Stockholms universitet, 10691 Stockholm, Sverige.

E-post: sara.snoder@isd.su.se

Christina Hedman är professor i svenska som andraspråk med didaktisk inriktning vid Stockholms universitet. Hennes forskning omfattar utveckling och användning av språk och litteracitet hos flerspråkiga barn och ungdomar i ett undervisningsperspektiv, även språkideologi och språkpolicy.

Institutionsanknytning: Institutionen för språkdidaktik, Stockholms universitet, 10691 Stockholm, Sverige.

E-post: christina.hedman@isd.su.se

Joke Dewilde är docent i flerspråkighet i utbildning vid Universitetet i Oslo. Bland hennes forskningsintressen kan nämnas flerspråkiga lärare, transspråkande och litteracitet, samt lingvistisk etnografi i utbildningskontexter.

Institutionsanknytning: Institutt for lærerutdanning og skoleforskning, Universitetet i Oslo, Postboks 1099, Blindern, 0317 Oslo, Norge.

E-post: joke.dewilde@ils.uio.no 


\section{Referenser}

Ag, A. \& Jørgensen, J. N. (2013). Ideologies, norms, and practices in youth poly-languaging. International Journal of Bilingualism, 17(4), 525-539.

https://doi.org/10.1177/1367006912457275

Agar, M. (2006). An ethnography by any other name ... Forum: Qualitative Sozialforschung / Forum: Qualitative Social Research, 7(4), Article 36. https://doi.org/10.17169/fqs-7.4.177

Bailey, E. G. \& Marsden, E. (2017). Teachers’ views on recognising and using home languages in predominantly monolingual primary schools. Language and Education, 31(4), 283-306. https://doi.org/10.1080/09500782.2017.1295981

Bigestans, A. (2015). Utmaningar och möjligheter för utländska lärare som återinträder i yrkeslivet i svensk skola. Doktorsavhandling, Stockholms universitet. https://www.diva-portal.org/smash/record.jsf?pid=diva2:773560

Blommaert, J. \& Jie, D. (2010). Ethnographic fieldwork: A beginner's guide. Multilingual Matters.

Bonacina-Pugh, F. (2020). Legitimizing multilingual practices in the classroom: The role of the 'practiced language policy'. International Journal of Bilingual Education and Bilingualism, 23(4), 434-448. https://doi.org/10.1080/13670050.2017.1372359

Boyd, S. (2003). Foreign-born teachers in the multilingual classroom in Sweden: The role of attitudes to foreign accent. I A. Creese \& P. Martin (red.), Mutilingual classroom ecologies: Inter-relationship, interactions and ideologies (s. 123-135). Bristol, Blue Ridge Summit; Multilingual Matters. https://doi.org/10.21832/9781853596964-009

Bredänge, G. (2003). Gränslös pedagog. Fyra studier om utländska lärare i svensk skola. Doktorsavhandling, Göteborgs universitet. Acta Universitatis Gothoburgensis.

Bryman, A. (2018). Samhällsvetenskapliga metoder. Liber.

Bucholtz, M. (2000). The politics of transcription. Journal of Pragmatics, 32(10), 1439-1465. https://doi.org/10.1016/S0378-2166(99)00094-6

Canagarajah, S. (2006). Ethnographic methods in language policy. I T. Ricento (red.), An introduction to language policy: Theory and method (s. 153-168). Blackwell Publ.

Conteh, J. (2018). From the margins to the centre: Multilingual teachers in a monolingual system: Professional identities, skills and knowledge. I P. Van Avermaet, S. Slembrouck, K. Van Gorp, S. Sierens \& K. Maryns (red.), The Multilingual Edge of Education (s. 211233). Palgrave Macmillan.

Conteh, J., Copland, F. \& Creese, A. (2014). Multilingual teachers' resources in three different contexts: Empowering learning. I J. Conteh \& G. Meier (red.), The multilingual turn in languages education. Opportunities and challenges (s. 158-179). Multilingual Matters.

Copland, F. \& Creese, A. (2015). Linguistic ethnography: Collecting, analysing and presenting data. SAGE Publications Ltd. https://doi.org/10.4135/9781473910607

Creese, A. (2005). Teacher collaboration and talk in multilingual classrooms. Multilingual Matters.

Creese, A. \& Blackledge, A. (2010). Translanguaging in the Bilingual Classroom: A Pedagogy for Learning and Teaching? The Modern Language Journal, 94(1), 103-115. https://doi.org/10.1111/j.1540-4781.2009.00986.x

Cummins, J. (2014). Rethinking pedagogical assumptions in Canadian French immersion programs. Journal of Immersion and Content-Based Language Education, 2(1), 3-22. https://doi.org/10.1075/jicb.2.1.01cum 
Daugaard, L. M. (2015). Sproglig praksis i og omkring modersmålsundervisning. En lingvistisk etnografisk undersøgelse. Doktorsavhandling, Aarhus Universitet. https://viden.sl.dk/media/5099/sproglig-praksis-i-og-omkringmodermaalsundervisning.pdf

Daugaard, L. M. \& Dewilde, J. (2017). Flerspråklige lærere som opfindere - i danske og norske skoler. Nordand, 12(1), 6-22. https://doi.org/10.18261/issn.2535-3381-2017-01-02

Davies, B. \& Harré, R. (1990). Positioning: The discursive production of selves. Journal for the Theory of Social Behaviour, 20(1), 43-63. https://doi.org/10.1111/j.1468-5914.1990.tb00174.x

Dávila, L. T. \& Bunar, N. (2020). Translanguaging through an advocacy lens: The roles of multilingual classroom assistants in Sweden. European Journal of Applied Linguistics, 8(1), 107-126. https://www.degruyter.com/document/doi/10.1515/eujal-2019-0012/html

De Fina, A. (2019). The Interview as an interactional event. I P. L. Patrick, M. S. Schmid \& $\mathrm{K}$. Zwaan (red.), Language analysis for the determination of origin: Current perspectives and new directions (s. 21-40). Springer International Publishing. https://doi.org/10.1007/978-3-319-79003-9_2

Dewilde, J. (2013). Ambulating teachers. A case study of bilingual teachers and teacher collaboration. Doktorsavhandling, Universitetet i Oslo. http://urn.nb.no/URN:NBN:no-58397

Duek, S. (2017). Med andra ord: Samspel och villkor för litteracitet bland nyanlända barn. Doktorsavhandling, Karlstad universitet.

Fairclough, N. (2014). Language and power. Routledge.

Foucault, M. (1993). Diskursens ordning: Installationsföreläsning vid Collège de France den 2 december 1970. B. Östlings bokförlag Symposion.

Foucault, M., Rabinow, P., Faubion, J. D. \& Hurley, R. (2000). Essential works of Foucault, 1954-1984. Vol. 3, Power. The New Press.

Ganuza, N. \& Hedman, C. (2015). Struggles for legitimacy in mother tongue instruction in Sweden. Language and Education, 29(2), 125-139. https://doi.org/10.1080/09500782.2014.978871

Gilham, P. \& Fürstenau, S. (2020). The relationship between teachers' language experience and their inclusion of pupils' home languages in school life. Language and Education, 34(1), 36-50. https://doi.org/10.1080/09500782.2019.1668008

Gogolin, I. (2002). Linguistic and cultural diversity in Europe: A challenge for educational research and practice. European Educational Research Journal, 1(1), 123-138. https://doi.org/10.2304/eerj.2002.1.1.3

Hall, K. A., Özerk, K., Zulfiqar, M. \& Tan, J. E. C. (2002). “This is our school”: Provision, purpose and pedagogy of supplementary schooling in Leeds and Oslo. British Educational Research Journal, 28(3), 399-418. https://doi.org/10.1080/01411920220137467

Hedman, C. \& Magnusson, U. (2019). Performative functions of multilingual policy in second language education in Sweden. International Journal of Bilingual Education and Bilingualism, 1-15. https://doi.org/10.1080/13670050.2019.1693956

Hedman, C. \& Magnusson, U. (2020). Teachers' acts of legitimation in second language education in Swedish upper secondary schools. Language and Education, 34(6), 535-552. https://doi.org/10.1080/09500782.2020.1775245

Heller, M. (1996). Legitimate language in a multilingual school. Linguistics and Education, 8(2), 139-157. https://doi.org/10.1016/S0898-5898(96)90011-X

Hornberger, N. H. (2006). Frameworks and models in lanuage policy and planning. I T. Ricento (red.), An introduction to language policy: Theory and method (s. 23-41). Blackwell Publ. 
Hornberger, N. H. \& Johnson, D. C. (2007). Slicing the onion ethnographically: Layers and spaces in multilingual language education policy and practice. TESOL Quarterly, 41(3), 509-532. https://doi.org/10.1002/j.1545-7249.2007.tb00083.x

Hult, F. M. \& Hornberger, N. H. (2016). Revisiting orientations in language planning: Problem, right, and resource as an analytical heuristic. GSE Publication, 33(3), 30-49.

Jönsson, A. \& Rubinstein Reich, L. (2004). Invandrade akademiker som lärare i den svenska skolan. Institutet för arbetsmarknadspolitisk utvärdering.

Jönsson, A. \& Rubinstein Reich, L. (2006). En yrkesidentitet i förändring? Invandrade lärares möte med den svenska skolan. Pedagogisk forskning i Sverige, 11(8), 81-93.

Kvale, S. \& Brinkmann, S. (2014). Den kvalitativa forskningsintervjun. Studentlitteratur.

Li Wei (2018). Translanguaging as a Practical Theory of Language. Applied Linguistics, 39(1), 9-30. https://doi.org/10.1093/applin/amx039

Lindberg, I. (2009). I det nya mångspråkiga Sverige. Utbildning \& demokrati, 18(2), 9-37.

Martin-Jones, M. \& Saxena, M. (2003). Bilingual resources and "funds of knowledge" for teaching and learning in multi-ethnic classrooms in Britain. International Journal of Bilingual Education and Bilingualism, 6(3-4), 267-282. https://doi.org/10.1080/13670050308667785

Ochs, E. (1979). Transcription as theory. I B. Schieffelin \& E. Ochs (red.), Developmental pragmatics (s. 167-182). Academic Press.

Rampton, B., Maybin, J. \& Roberts, C. (2015). Theory and method in linguistic ethnography. I J. Snell, S. Shaw \& F. Copland (red.), Linguistic ethnography: Interdisciplinary explorations (s. 14-48). Palgrave MacMillan.

Reath Warren, A. (2017). Developing multilingual literacies in Sweden and Australia: Opportunities and challenges in mother tongue instruction and multilingual study guidance in Sweden and community language education in Australia. Doktorsavhandling, Stockholms universitet. https://su.diva-portal.org/smash/get/diva2:1116085/FULLTEXT01.pdf

Ricento, T. (2006). An introduction to language policy: Theory and method : Language and social change. Blackwell Publ.

Rosén, J., Straszer, B. \& Wedin, Å. (2019). Studiehandledning på modersmål. Studiehandledares positionering och yrkesroll. Educare, 2019(3), 1-13.

Ruíz, R. (1984). Orientations in language planning. Bilingual Research Journal, 8(2), 15-34. https://doi.org/10.1080/08855072.1984.10668464

Ruíz, R. (2010). Reorienting language-as-resource. I J. Petrovic (red.), International perspectives on bilingual education: Policy, practice, and controversy (s. 155-172). Information Age Publishing.

Ryan, G. W. \& Bernard, H. R. (2003). Techniques to identify themes. Field Methods, 15(1), 85-109. https://doi.org/10.1177/1525822X02239569

Safford, K. \& Kelly, A. (2010). Linguistic capital of trainee teachers: Knowledge worth having? Language and Education, 24(5), 401-414. https://doi.org/10.1080/09500781003695567

Salö, L. (2018). Seeing the point from which you see what you see: An essay on epistemic reflexivity in language research. Multilingual Margins, 5(1), 24-39.

Sandlund, M. (2010). Lärare med utländsk bakgrund. Sju yrkeslivsberättelser om möten med nya skolsammanhang. Doktorsavhandling, Linköpings universitet. https://www.diva-portal.org/smash/get/diva2:377626/FULLTEXT01.pdf

SFS 2009:600. Språklag (2009:600). Svensk författningssamling 2009:600-Riksdagen. Kulturdepartementet. https://www.riksdagen.se/sv/dokument-lagar/dokument/svenskforfattningssamling/spraklag-2009600_sfs-2009-600 
Skolverket (2019a). Läroplan för grundskolan, förskoleklassen och fritidshemmet. https://www.skolverket.se/undervisning/grundskolan/laroplan-och-kursplaner-forgrundskolan

Skolverket (2019b). Sök statistik om förskola, skola och vuxenutbildning. https://www.skolverket.se/skolutveckling/statistik/sok-statistik-om-forskola-skola-ochvuxenutbildning

Svensson, G., Rosén, J., Straszer, B. \& Wedin, Å. (2018). Greppa flerspråkigheten: En resurs i lärande och undervisning. Skolverket.

Talmy, S. (2011). The interview as collaborative achievement: Interaction, identity, and ideology in a speech event. Applied Linguistics, 32(1), 25-42. https://doi.org/10.1093/applin/amq027

Van Leeuwen, T. (2007). Legitimation in discourse and communication. Discourse \& Communication, 1(1), 91-112. https://doi.org/10.1177/1750481307071986

Vetenskapsrådet (2017). God forskningssed. Vetenskapsrådet. https://www.vr.se/download/18.2412c5311624176023d25b05/1555332112063/Godforskningssed_VR_2017.pdf

Wodak, R. (2009). The discourse of politics in action: Politics as usual. Palgrave Macmillan. http://dx.doi.org/10.1057/9780230316539 